Faculty of Public Health and Policy, London School of Hygiene and Tropical Medicine, London

2 School of Law, University of Sheffield, Sheffield

3 Nuffield Trust, London

4 Department of Health Policy, London School of Economics, London

Cite this as: BMJ 2020;371:m4439 http://dx.doi.org/10.1136/bmi.m4439 Published: 17 November 2020

BRIEFING

\title{
How will Brexit affect the healthcare workforce?
}

\section{As part of a series of briefings as we near the end of the Brexit transition period, May van Schalkwyk and colleagues look at its potential impact on NHS and social care staff}

May C I van Schalkwyk, ${ }^{1}$ Tamara K Hervey, ${ }^{2}$ Martha McCarey, ${ }^{3}$ Mark Dayan, ${ }^{3}$ Pepita Barlow, ${ }^{4}$ Martin McKee ${ }^{1}$

\section{Do we have good data on how many EU doctors work in the UK?}

Data are collected on the nationality of NHS staff, but there are questions about the accuracy of some of these data and a number of other problems with the arrangements around how they're maintained and updated.

All NHS employees have an electronic staff record containing their details, and this includes their nationality when recruited. However, the information is monitored in separate systems in each of the four nations (in England, it's the responsibility of NHS Digital). There's also no obligation for NHS workers who acquire British nationality to update their information, and there's no record of whether this has happened. So, some doctors may be misclassified as not having British nationality (because they haven't updated their records), while others won't be recorded as coming from the EU (because they have updated their records). It's also not clear how the system deals with dual nationals, including the large number with joint UK and Irish nationality.

The General Medical Council (GMC) also monitors the movement of doctors to and from all four UK nations. However, the only indicator of national affiliation in the GMC record is the country of primary qualification. Thus, British citizens qualifying abroad would be considered overseas graduates, while EU citizens qualifying in the UK would be UK graduates.

\section{Do we know whether more EU doctors have left the UK in recent years or whether fewer are now coming to the UK?}

Over the past two years the overall number of staff from the EU working in the NHS in England has remained stable, at around $5.5 \%$ of all staff. ${ }^{1}$ The picture for doctors specifically is also one of relative stability, in data from both NHS Digital (for which EU doctors are defined by nationality on NHS records) and the GMC (for which EU doctors are defined by country of qualification). For instance, NHS Digital data show that 490 EU doctors left NHS trusts in England in March and April 2019, and 432 did so in March and April 2020.

The NHS Digital and the GMC figures show that, although the number of EU qualified doctors has increased over the past two years, the rate of this increase has been lower than among overseas doctors from outside the EU. The number of EU qualified doctors increased by $2.9 \%$ in $2018-19$ and by $8.2 \%$ in
2019-20, whereas the number of overseas qualified doctors from outside the EU rose by $7.4 \%$ and $13.2 \%$ over those two periods.

However, doctors don't work in isolation from other staff, so we also need to think about staffing across the entire health and social care system, including support staff, research scientists, nurses, and social care staff. From 2018 to 2020 the overall headcount of EU nurses and health visitors in NHS trusts in England has slightly decreased, although numbers from the rest of the world are increasing in a more sustained manner.

\section{Some regions face particular staffing}

challenges-such as Northern Ireland, which draws on the same labour market for health workers as the Republic of Ireland, with considerable cross border working. The wider environment for immigrant labour should also be considered, as it's likely to affect EU and other overseas citizens coming to the UK.

\section{What effect might Brexit, deal or no deal, have on the NHS's ability to attract and recruit doctors from the EU?}

There are many uncertainties around this, and they make it difficult to predict future levels of medical migration.

Firstly, will the restrictions on free movement for EU citizens be sustainable? There is widespread recognition that a no deal or minimalist Brexit deal can only be a temporary situation given the disruption it will create, ${ }^{2}$ and UK governments in the future will face a permanent economic incentive to change course. More widely, although the UK government has placed stricter migration controls at the centre of its case for Brexit, in the longer term it may have difficulty sustaining this as it tries to negotiate trade deals with countries such as India, which will want greater opportunities for their citizens to come to the UK.

NHS Employers and the Institute for Public Policy Research have both raised concerns about the impact of the new points based immigration system on recruitment to social care. ${ }^{45}$ In addition, the BMA has called for the UK government to establish a flexible migration system that promotes entry into the UK for health and social care staff, as well as allowing UK trained doctors to work in the EU. ${ }^{6}$

Secondly, if barriers to entry remain, will potential migrants consider them too expensive and burdensome? The UK's reputation among potential 
migrants has been damaged by the government's "hostile environment" approach ${ }^{7}$ and its treatment of the Windrush generation. ${ }^{8}$ As of November 2020 there's little clarity about the fees that incoming doctors will have to pay, and the Home Office is known to view such charges as a valuable revenue stream. Workers will also need reassurance about ease of entry for their spouses and dependants-and their ability to also work and access healthcare, as well as other services such as education. ${ }^{9}$

Thirdly, for workers who are supporting relatives in their country of origin, the declining value of the pound may mean that the value of their remissions falls.

\section{What might a well negotiated Brexit outcome look like, in terms of EU healthcare professionals working in the UK?}

Any form of Brexit will make the UK a less attractive destination for EU health professionals. They will lack certainty about many practical issues, such as taxation, portability of pensions, and their right to remain in the long term.

The UK's refusal to issue documentation specifying that people with "settled status" have the right to remain in the UK is already causing problems for those seeking to access services, use banks, or rent property. ${ }^{10}$ The current UK guidance lacks detail, stating only that the UK will continue to recognise European Economic Area and Swiss qualifications “for a temporary period" after 1 January $2021 .{ }^{11}$ This approach is consistent with the many other areas ${ }^{12}$ where the UK has delayed making a final decision for as long as possible, going beyond the end of the transition where it can.

If an EU-UK trade agreement is reached, continued recognition of each other's qualification frameworks for health and care staff will be feasible, and the EU and UK draft texts both propose a framework for collaboration here. Unless the UK decides to diverge significantly from EU medical professional standards, we may see relative continuity in this context.

However, exchange of information about fitness to practise cannot occur, as the UK will lose access to the EU's Internal Market Information system because it insists on leaving the internal market. Increased vigilance over fitness to practise will therefore be critical to maintaining standards of patient care. ${ }^{13}$

The outcome of the negotiations will have implications for working conditions. The EU wants to secure a non-regression clause in labour standards, whereas the UK wants the ability to develop standards independently. If there is no agreement, erosion of employment conditions may compound the impact of immigration changes on staffing levels. However, domestic law and policy could embed working conditions in practice: the terms of junior doctors' contracts in England include existing working time rules based on EU law, although these protections have long been a target of Brexit supporters. ${ }^{13} 14$

\section{After the end of the transition period, what might still attract EU doctors to work in the UK?}

The UK continues to have a strong research record in life sciences. However, this is threatened by Brexit, especially if there's no deal-with the UK losing access to European Reference Networks, for example, and potential obstacles to collaboration on clinical trials. ${ }^{15}$ Negotiations on the UK's continuing inclusion in Horizon Europe, one of the most ambitious research collaborations globally, have reached an impasse. ${ }^{16}$
Since the 2016 EU referendum the reported levels of race related hate crimes have increased in the UK, ${ }^{17}{ }^{18}$ and while the most recent NHS staff survey revealed an increase in staff morale and patient safety scores, almost 40000 of respondents (7.2\%) reported experiencing discrimination from patients in the past year, an increase from $5.8 \%$ in $2015 .{ }^{19}$ In a 2018 study, most EU doctors who were interviewed reported that the referendum and its political aftermath had given rise to feelings of uncertainty and of being unwanted and undervalued. ${ }^{20}$

Persuading those doctors to stay will be contingent on building confidence that future work conditions will not deteriorate-and reassurance that they are wanted and valued. ${ }^{20}$

MvS is funded by an NIHR doctoral fellowship (ref NIHR300156). TKH acknowledges the support of the Economic and Social Research Council's Health Governance After Brexit project (ES/S00730X/1). The views presented here are those of the authors and should not be attributed to the above funding organisations, their directors, officers, or staff.

Competing interests: None declared.

Provenance and peer review: Commissioned; not peer reviewed.

House of Commons Library. NHS staff from overseas: statistics. 4 Jun 2020. https://researchbriefings.files.parliament.uk/documents/CBP-7783/CBP-7783.pdf.

2 Savage M. UK industry chief says business needs more from "thin” Brexit deal. Guardian 2020 Nov 1. https://www.theguardian.com/politics/2020/nov/01/uk-industry-chief-says-businessneeds-more-from-thin-brexit-deal.

Sengupta K. UK post-Brexit trade deal with India threatened by Theresa May’s visa crackdown. Independent2017 Jan 18. https://www.independent.co.uk/news/uk/politics/brexit-uk-britain-indiatrade-deal-freedom-movement-delhi-boris-johnson-a7534026.html.

$4 \quad$ NHS Confederation. Immigration announcement provides no obvious solution for social care. 19 Feb 2020. https://www.nhsconfed.org/news/2020/02/response-to-immigration-policy-announcement.

5 Institute for Public Policy Research. New migration system risks Covid economic recovery due to curbs on carers and key workers, warns IPPR. 3 Nov 2020. https://www.ippr.org/news-and media/press-releases/new-migration-system-risks-covid-economic-recovery-due-to-curbs-oncarers-and-key-workers-warns-ippr.

6 BMA. BMA and Brexit. 7 Sep 2020. https://www.bma.org.uk/what-we-do/working-with-europe/brexit/bma-and-brexit.

7 Hiam L, Steele S, McKee M. Creating a "hostile environment for migrants": the British government's use of health service data to restrict immigration is a very bad idea. Health Econ Policy Law 2018;13:107-17. doi: 10.1017/S1744133117000251. pmid: 29306349

$8 \quad$ McKee M. Lessons from the Windrush generation. BMJ 2018;361:k2017. doi: 10.1136/bmj.k2017 pmid: 29739792

9 O'Carroll L. UK to face questions over Northern Ireland citizenship laws. Guardian 2019 Oct 14. https://www.theguardian.com/uk-news/2019/oct/14/uk-court-rules-against-derry-woman-inirish-identity-case.

10 Tims A. Brexit: EU citizens in UK could be shut out of vital services. Guardian 2020 Sep 6. https://www.theguardian.com/politics/2020/sep/26/eu-citizens-uk-brexit-settled-status-jobsbanking-healthcare.

11 UK Government. Get your EEA qualification recognised in the UK from 1 January 2021. 12 Oct 2018. https://www.gov.uk/guidance/get-your-eea-qualification-recognised-in-the-uk-from-1-january-2021.

12 Wishart I. Brexit negotiators move close to breaking impasse over fish. Bloomberg 2020 Nov 1. https://www.bloomberg.com/news/articles/2020-11-01/brexit-negotiators-move-close-tobreaking-key-impasse-over-fish.

13 Fahy N, Hervey T, Dayan M, etal. Assessing the potential impact on health of the UK's future relationship agreement with the EU: analysis of the negotiating positions. Health Econ Policy Law 2020:1-18. doi: 10.1017/S1744133120000171. pmid: 32487272

14 Dobbins T. Tory attack on Working Time Directive signals a post-Brexit race to the bottom. Conversation 2017 Dec 20. https://theconversation.com/tory-attack-on-working-time-directivesignals-a-post-brexit-race-to-the-bottom-89395.

15 Fahy N, Hervey T, Greer S, etal. How will Brexit affect health services in the UK? An updated evaluation. Lancet 2019;393:949-58. doi: 10.1016/S0140-6736(19)30425-8. pmid: 30819519

16 O'Carroll L. Brexit: $£ 3$ bn standoff over UK-EU scientific collaboration. 22 Oct 2020. https://www.theguardian.com/science/2020/oct/22/science-brexit-deal-faces-3bn-hurdle-in-eufunding-programme-uk-horizon-europe.

17 Brexit "major influence" in racism and hate crime rise. BBC News 2019 Jun 19. https://www.bbc.co.uk/news/uk-wales-48692863.

18 Booth R. Racism rising since Brexit vote, nationwide study reveals. Guardian 2019 May 20. https://www.theguardian.com/world/2019/may/20/racism-on-the-rise-since-brexit-vote-nationwide-study-reveals. 
19 NHS. NHS staff morale improves but too many facing abuse. 18 Feb 2020. https://www.england.nhs.uk/2020/02/nhs-staff-morale-improves-but-too-many-facing-abuse/.

20 Chick W, Exworthy M. Post-Brexit views of European Union doctors on their future in the NHS: a qualitative study. BMJ Leader 2018;2:20-4. doi: 10.1136/leader-2017-000049. 